
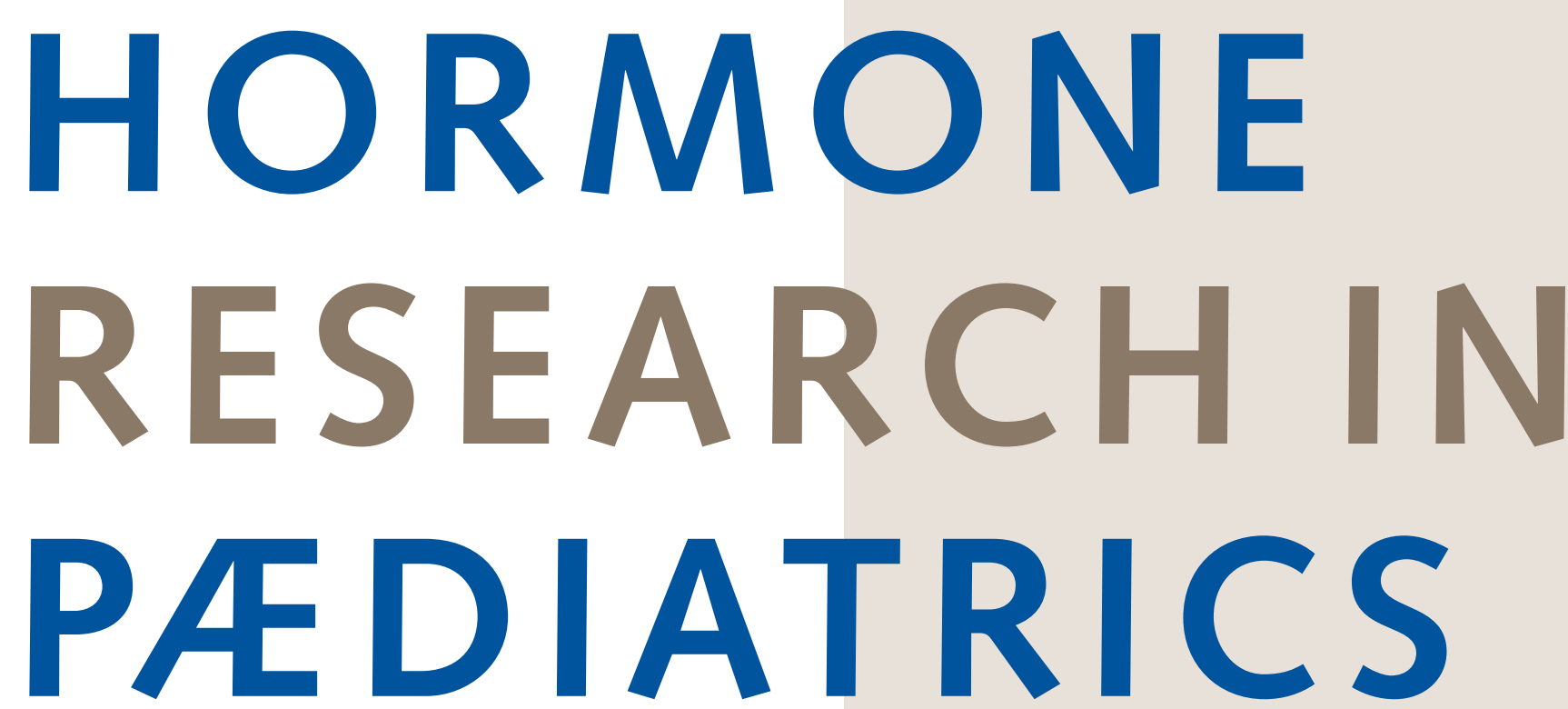

From Developmental Endocrinology to Clinical Research

\title{
Genetics of Growth
}




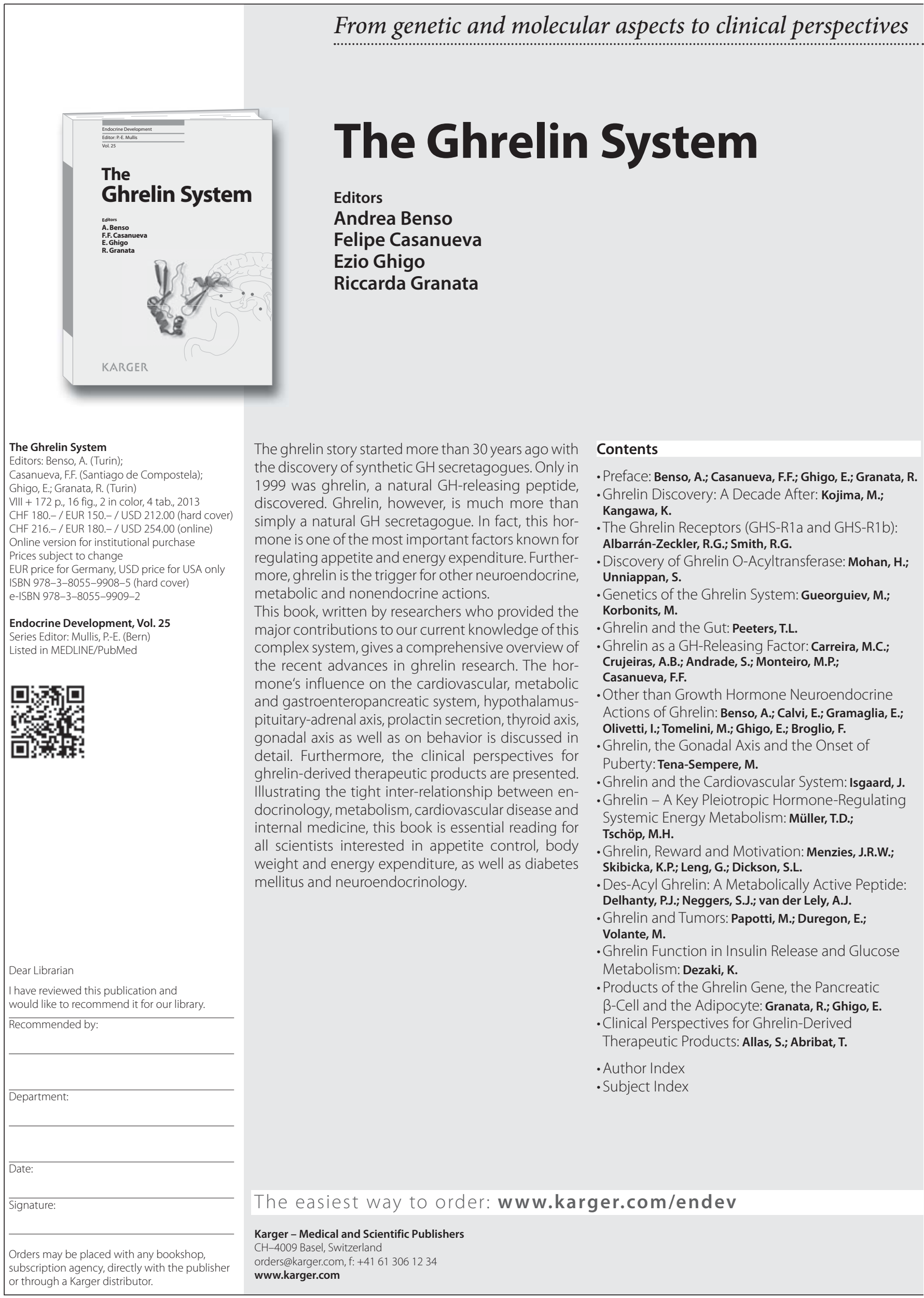


Official Journal of

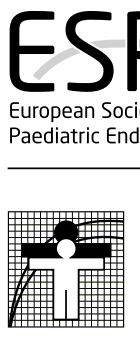

\section{SLEP}

Sociedade Latino-Americana de Endocrinologîa Pediátrica

HORMONE

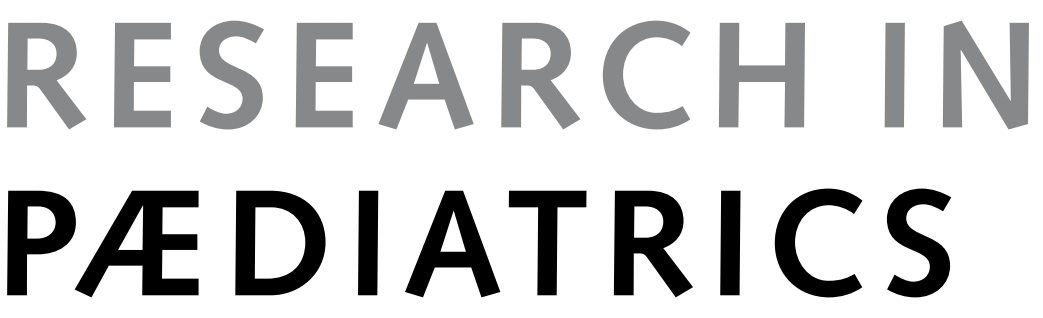

From Developmental Endocrinology to Clinical Research

Founded 1970 as 'Hormones' by M. Marois

Continued by J. Girard (1976-1995); M.B. Ranke (1996-2003)

Editorial Board

I.J.P. Arnhold, São Paulo

J.-P. Bourguignon, Liège

J.-C. Carel, Paris

F. Cassorla, Santiago

J.-P. Chanoine, Vancouver, B.C.

P.E. Clayton, Manchester

H. Delemarre-van de Waal, Leiden

M. Donaldson, Glasgow

D.B. Dunger, Cambridge

L. Dunkel, London

U. Feldt-Rasmussen, Copenhagen

J.J. Heinrich, Buenos Aires

A.C. Hokken-Koelega, Rotterdam
A. Hübner, Dresden

K.Y. Loke, Singapore

C.J. Migeon, Baltimore, Md.

M. Phillip, Petah Tikva

M. Polak, Paris

M.B. Ranke, Tübingen

R.G. Rosenfeld, Palo Alto, Calif.

D.E. Sandberg, Ann Arbor, Mich.

M.O. Savage, London

T. Tanaka, Tokyo

G. Van Vliet, Montreal, Que.

R. Verkauskiene, Kaunas

R.J. Voutilainen, Kuopio

P. Saenger, Bronx, N.Y.

O. Söder, Stockholm

J.M. Wit, Leiden

\section{ESPE Council 2012-2013}

Secretary General

L. Sävendahl, Stockholm

President

F. Chiarelli, Chieti

President Elect

H. Hoey, Dublin

Chairman of Strategic and Finance Committee

A. Hokken-Koelega, Rotterdam

Chairman of Clinical Practice

Committee

G. Butler, London
Chairman of Education and Training Committee

J. Lebl, Prague

Chairman of Programme Organising Committee

J.-C. Carel, Paris

(Chairman Elect: M. Dattani, London)

Chairman of Corporate Liaison Board P. Clayton, Manchester

Member (responsible for communications)

G. Chrousos, Athens 
HORMONE

\section{RESEARCH IN PAEDIATRICS}

\section{Aim and Scope}

Hormone Research in Paediatrics aims to provide rapid publication of clinical investigations, mini reviews and novel insights from clinical experience, as well as experimental and methodological work related to paediatric and adolescent endocrinology. Correspondence is welcome, but publication of letters is at the discretion of the editors.

\section{Submission}

Manuscripts written in English should be submitted using the online submission website at:

\section{www.karger.com/hrp}

Should you have any problems with your submission, please contact the Editorial Office:

\section{hrp@karger.com}

Prof. P. Czernichow

S. Karger AG

Editorial Office 'Hormone Research in Paediat-

rics'

P.O. Box

CH-4009 Basel (Switzerland)

Tel. +41613061437

Fax +41613061434

They should be accompanied by a signed copyright transfer statement (please see submission website). The names and addresses of four experts in the appropriate area of research should accompany each manuscript. Selected scientist(s) will be invited to act as referee(s).

\section{Main Sections}

1. Original papers

Any original papers on hormone research are accepted; we particularly welcome papers on developmental and clinical research.

\section{Mini reviews}

Most mini reviews are submitted upon invitation. However, the editors are open to unsolicited mini reviews. Authors planning such a mini review are requested to contact the Editorial Office with an outline of the intended mini review. All mini reviews are subject to peer review. The guidelines for the mini reviews can be found at www.karger. com/hrp_guidelines\# 11.

3. Novel insights from clinical practice

We invite contributions to this section that provide novel insight into a clinical problem. We recognise the value of case reports and thus submissions can be based around a case or a number of similar cases. The most important aspect of the presentation is that it should provide a new perspective on a recognised clinical scenario or may represent an entirely new clinical condition. The novel aspects of the case(s) may be in the phenotype, the presentation, the investigation and/or the management. This category replaces the previous case report section.

We propose that a highlighted box containing one or two bullet points on 'Established facts' and 'Novel insights' be placed on the first page of the report. This reinforce the novelty of the clinical observation. The manuscript should be presented with an abstract (up to 200 words), brief introduction, case or case series description and results, followed by a discussion. No limits on length or number of references are imposed. Statements for the highlighted box should also be included.

\section{Conditions}

All manuscripts are subject to editorial review. The names and addresses of four experts in the appropriate area of research should accompany each manuscript. Selected scientist(s) will be invited to act as referee(s)

Manuscripts are received with the explicit understanding that they are not under simultaneous consideration by any other publication. Submission of an article for publication implies the transfer of the copyright from the author to the publisher upon acceptance. Accepted papers become the permanent property of Hormone Research in Paediatrics and may not be reproduced by any means, in whole or in part, without the written consent of the publisher.

It is the author's responsibility to obtain permission to reproduce illustrations, tables, etc. from other publications.

\section{Arrangement}

Title page: The first page of each paper should indicate the title, the authors' names, the institute where the work was conducted, and a short title for use as running head.

Full address: The exact postal address of the corresponding author complete with postal code must be given at the bottom of the title page. Please also supply phone and fax numbers, as well as e-mail address. Key words: Please supply 3-10 key words in English that reflect the content of the paper.

Abstract: Each paper needs an abstract of up to 200 words. It should be structured as follows:

Background/Aims: What is the major problem that prompted the study?

Methods: How was the study done?

Results: Most important findings?

Conclusion: Most important conclusion?

Footnotes: Avoid footnotes. When essential, they are numbered consecutively and typed at the foot of the appropriate page.

Tables and illustrations: Tables and illustrations (both numbered in Arabic numerals) should be prepared on separate pages. Tables require a heading and figures a legend, also prepared on a separate page. Due to technical reasons, figures with a screen background should not be submitted. When possible, group several illustrations on one block for reproduction (max. size $180 \times 223 \mathrm{~mm}$ ) or provide crop marks.

\section{Color illustrations}

Online edition: Color illustrations are reproduced free of charge. In the print version, the illustrations are reproduced in black and white. Please avoid referring to the colors in the text and figure legends.

Print edition: Up to 6 color illustrations per page can be integrated within the text at CHF 800.- per page.

References: In the text identify references by Arabic numerals [in square brackets]. Material submitted for publication but not yet accepted should be noted as 'unpublished data' and not be included in the reference list. The list of references should include only those publications which are cited in the text. Do not alphabetize; number references in the order in which they are first mentioned in the text. The surnames of the authors followed by initials should be given. There should be no punctuation other than a comma to separate the authors. Preferably, please cite all authors. Abbreviate journal names according to the Index Medicus system. Also see International Committee of Medical Journal Editors: Uniform requirements for manuscripts submitted to biomedical journals (www.icmje.org).

Examples

(a) Papers published in periodicals: Sun J, Koto H, Chung KF: Interaction of ozone and allergen challenges on bronchial responsiveness and inflammation in sensitised guinea pigs. Int Arch Allergy Immunol 1997;112:191-195.

(b) Papers published only with DOI numbers:

Theoharides TC, Boucher W, Spear K: Serum interleukin-6 reflects disease severity and osteoporosis in mastocytosis patients. Int Arch Allergy Immunol DOI: $10.1159 / 000063858$

(c) Monographs: Matthews DE, Farewell, VT: Using and Understanding Medical Statistics, ed 3, revised. Basel, Karger, 1996.

(d) Edited books: Parren PWHI, Burton DR: Antibodies against HIV-1 from phage display libraries: Mapping of an immune response and progress towards antiviral immunotherapy; in Capra JD (ed): Antibody Engineering. Chem Immunol. Basel, Karger, 1997, vol 65, pp 18-56.

Reference Management Software: Use of EndNote is recommended for easy management and formatting of citations and reference lists.

\section{Digital Object Identifier (DOI)}

S. Karger Publishers supports DOIs as unique identifiers for articles. A DOI number will be printed on the title page of each article. DOIs can be useful in the future for identifying and citing articles published online without volume or issue information. More information can be found at www.doi.org.

\section{Supplementary Material}

Supplementary material is restricted to additional data that are not necessary for the scientific integrity and conclusions of the paper. Please note that all supplementary files will undergo editorial review and should be submitted together with the origina manuscript. The Editors reserve the right to limit the scope and length of the supplementary material. Supplementary material must meet production quality standards for Web publication without the need for any modification or editing. In general, supplementary files should not exceed $10 \mathrm{MB}$ in size. All figures and tables should have titles and legends and all files should be supplied separately and named clearly. Acceptable files and formats are: Word or PDF files, Excel spreadsheets (only if the data cannot be converted properly to a PDF file), and video files (.mov, avi, .mpeg)

\section{Author's Choice ${ }^{\mathrm{TM}}$}

Karger's Author's Choice ${ }^{\mathrm{TM}}$ service broadens the reach of your article and gives all users worldwide free and full access for reading, downloading and printing at www.karger.com. The option is available for a onetime fee of CHF 3,000.-, which is a permissible cost in grant allocation. More information can be found at www.karger.com/authors_choice.

\section{NIH-Funded Research}

The U.S. National Institutes of Health (NIH) mandates under the NIH Public Access Policy that final peer-reviewed manuscripts appear in its digital database within 12 months of the official publication date. As a service to authors, Karger submits the final

\section{KARGER}

E-Mail karger@karger.com www.karger.com 
HORMONE

\section{RESEARCH IN PAEDIATRICS}

version of your article to PubMed Central, where it will appear after a standard embargo. More details on NIH's Public Access Policy are available at http:// publicaccess.nih.gov/policy.htm

\section{Self-Archiving}

Karger permits authors to archive their pre-prints (i.e. pre-refereeing) or post-prints (i.e. final draft post-refereeing) on their personal or institution's servers, provided the following conditions are met: Articles may not be used for commercial purposes, must be linked to the publisher's version, and must acknowledge the publisher's copyright.

\section{Page Charges}

There is no page charge for papers of 4 or fewer printed pages (including tables, illustrations and references). Each additional complete or partial page is charged to the author at CHF 650.-. The allotted size of a paper is equal to approx. 12 manuscript pages (including tables, illustrations and references). As the page charges are waived in any case for the first paper each year to be published by a member of ESPE, authors who are members of the ESPE should so indicate on the title page.

\section{Proofs}

Unless indicated otherwise, a PDF for correction is sent to the corresponding author and should be returned with the least possible delay. Alterations other than the correction of printer's errors are charged to the author.

\section{E-pub First}

All articles are published electronically ahead of print with a DOI number and are supplemented later with the definite reference of the printed version. The articles become available immediately after the authors approval to publication, with the added advantage of being citable much earlier than in print. Authors can influence the time of appearance by promptly returning the proofs.

\section{Reprints}

Order form and price list is sent with the PDF. Orders submitted after the issue is printed are subject to considerably higher prices.
Transforming Vesalius

The medical revolution of the 16th century brought to life for the 21st century

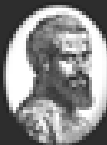

KARGER

Medical \& Scientific

Publishers
ANDREAS VESALIUS

The Fabric

\section{of the Human Body}

An Annotated Translation of the 1543 and 1555 Editions of "De Humani Corporis Fabrica" by

DANIEL H. GARRISON MALCOLM H. HAST

CXX + 1338 p., 340 fig., in two volumes, hard cover, with slip case, 2014 $12 \times 17^{\prime \prime} / 315 \times 435 \mathrm{~mm}, 16 \mathrm{~kg} / 35 \mathrm{lbs}$ CHF 1,500.- / EUR 1,250.- / USD 1,650.00 Postage and handling included For details see Vesalius website ISBN 978-3-318-02246-9

by
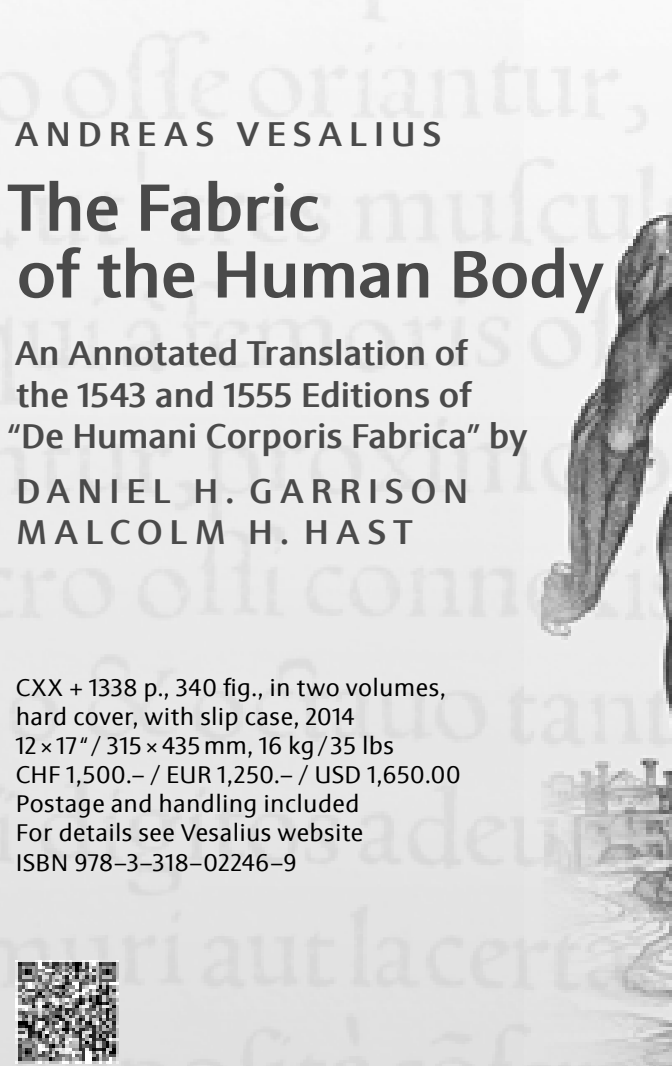

(c) 2013 S. Karger AG, Basel
For the first time ever, both editions of Andreas Vesalius' masterpiece "De Humani Corporis Fabrica" are accessible in the English language. They were critically compared and published in a modern layout transforming the Renaissance anatomical atlas for the $21 \mathrm{st}$-century reader. More than 5,000 annotations cover anything from antique sources over Galenic references to the medical and cultural background of Vesalius' time. To enable the reader and medical student to really study Vesalius' woodcut illustrations, the images were digitally enhanced and often enlarged to feature his painstaking work of marking each pertinent anatomical part with characters. All over Vesalius' descriptive text, the standard Latin Nomina Anatomica and Terminologia Anatomica provide the reader with the modern medical terminology.

For more information and easy ordering, please visit www.vesalius-fabrica.com 
HORMONE

\section{RESEARCH IN PAEDIATRICS}

ISSN Print Edition: 1663-2818

ISSN Online Edition: 1663-2826

Journal Homepage: www.karger.com/hrp

Publication Data: 'Hormone Research in Paediatrics' is published 12 times a year. Volumes 79 and 80 , each with 6 issues, appear in 2013.

Copyright: (c) 2013 S. Karger AG, Basel (Switzerland). All rights reserved. No part of this publication may be translated into other languages, reproduced or utilized in any form or by any means, electronic or mechanical, including photocopying, recording, microcopying, or by any information storage and retrieval system, without permission in writing from the publisher or, in the case of photocopying, direct payment of a specified fee to the Copyright Clearance Center.

Disclaimer: The statements, opinions and data contained in this publication are solely those of the individual authors and contributors and not of the publisher and the editor(s). The appearance of advertisements in the journal is not a warranty, endorsement, or approval of the products or services advertised or of their effectiveness, quality or safety. The publisher and the editor(s) disclaim responsibility for any injury to persons or property resulting from any ideas, methods, instructions or products referred to in the content or advertisements.
Subscription Rates: Subscriptions run for a full calendar year. Prices are given per year. Personal subscription:

Print or Online

CHF 1862.-

EUR 1502.-

USD 1844.00

Print+Online combined CHF 1958.-

EUR 1580.-

USD 1940.00

postage and handling (added to print and print+online)

CHF 86.40 Europe, CHF 124.80 Overseas

EUR 67.20

USD 115.20

Institutional subscription:

Print or Online

Print+Online combined

CHF 3722.-

EUR 3002.-

CHF 4094.-

USD 3686.00

USD 4054.00

postage and handling (added to print and print+online)

CHF 108.- Europe, CHF 156.- Overseas

EUR 84.-

USD 144.00

Airmail surcharge: CHF 105.- / USD 99.00

Discount subscription prices:

Pediatric Endocrine Society; International Society for Pediatric and Adolescent Diabetes (ISPAD); Schweizerische Gesellschaft für Endokrinologie; Asia Pacific Pediatric Endocrine Society (APPES). Subscription included in membership fee for members of the European Society for Paediatric Endocrinology (ESPE) and the Sociedade LatinoAmericana de Endocrinologia Pediátrica (SLEP).
Back Volumes and Single Issues: Information on availability and prices of single print issues and print or electronic back volumes can be obtained from Customer Service atservice@karger.com.

Bibliographic Indices: This journal is regularly listed in bibliographic services, including Current Contents ${ }^{\circledR}$ and PubMed/MEDLINE.

Photocopying: This journal has been registered with the Copyright Clearance Center (CCC), as indicated by the code appearing on the first page of each article. For readers in the US, this code signals consent for copying of articles for personal or internal use, or for the personal or internal use of specific clients, provided that the stated fee is paid per copy directly to

Copyright Clearance Center Inc.

222 Rosewood Drive

Danvers, MA 01923 (USA)

A copy of the first page of the article must accompany payment. Consent does not extend to copying for general distribution, for promotion, for creating new works, or for resale. In these cases, specific written permission must be obtained from the copyright owner,

S. Karger AG, P.O. Box

CH-4009 Basel (Switzerland).
Subscription Orders:

Orders can be placed at agencies, bookstores, directly with the Publisher

\section{S. Karger AG}

Medical and Scientific Publishers

Allschwilerstrasse 10

CH-4009 Basel

Switzerland

t: +41613061111

f: +41613061234

e: karger@karger.com

w: www.karger.com

(for courier services only:

Allschwilerstrasse 10

CH-4055 Basel)

or further Karger offices
or representatives:
Germany
S. Karger GmbH
Postfach
79095 Freiburg
Deutschland
(Hausadresse: Wilhelmstrasse 20A,
79098 Freiburg)
t: +49 761 452070
f: +49 7614520714
e: information@karger.de
w: www.karger.de
Japan
Karger Japan, Inc.
Shiba Daimon Asahi Bldg. 2F
1-2-23 Shiba Daimon
Minato-ku
Tokyo $105-0012$
Japan
t: +81 364356242
f: +81 364356244
e: publisher@karger.jp
w: www.karger.jp

USA

S. Karger Publishers, Inc.

26 West Avon Road

P.O. Box 529

Unionville, CT 06085

USA

Toll free: +18008285479

t: +18606757834

f: +18606757302

e: karger@snet.net

France

Enter \& Read

Albertine Luginbuhl

23, rue du Départ, boite 37

75014 Paris

France

t: $+33(0) 681047685$

e: albertineluginbuhl@orange.fr

South East Asia, China and Taiwan

Karger Regional Office (Malaysia)

CEO Suite Kuala Lumpur

Quill 7, 27th Floor

Jalan Stesen Sentral 5

KL Sentral

Kuala Lumpur 50470

Malaysia

t: $\quad+60327766803$

f: +60327766999

e: service@karger.cn

\section{Karger China}

West/5F, China Life Tower

No.16, Chao Wai Street

Chaoyang Distric

Beijing 100020

China

t: +861058771408

f: +861058771120

e: service@karger.cn; r.chew@karger.cn

w: www.karger.cn

India, Bangladesh, Sri Lanka

Karger India

Plot No. 17, Yusuf Sarai Marke

B.L. Glass Building, 2nd Floor

Sri Aurobindo Marg

New Delhi 110016

India

t: +911146029633

f: +911146029634

c: +919891052128

e: r.kumar@kargerindia.com

w: www.karger.com

Change of Address:

Both old and new address should be sent

to the subscription source.

\section{KARGER}

E-Mail karger@karger.com www.karger.com
(C) 2013 S. Karger AG, Basel

The Guidelines for Authors are available at: www.karger.com/hrp_Guidelines 


\section{Contents}

See the journal website for contents

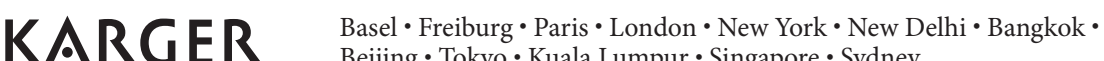
Beijing $\cdot$ Tokyo $\cdot$ Kuala Lumpur $\cdot$ Singapore $\cdot$ Sydney 


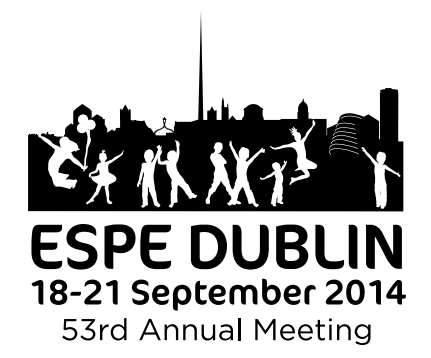

Prevention and

Therapeutic Innovations in

Paediatric Endocrinology

www.espe2014.org

\section{Céad mile failte*}

to the 53rd Annual Meeting

of the European Society for Paediatric Endocrinology

(ESPE 2014 Meeting) in Dublin

* 100000 welcomes

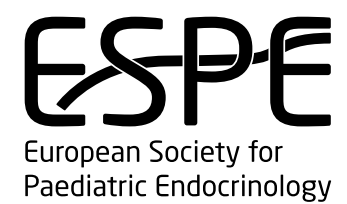




\section{Summarizing the latest advances in the fight against the obesity epidemic}

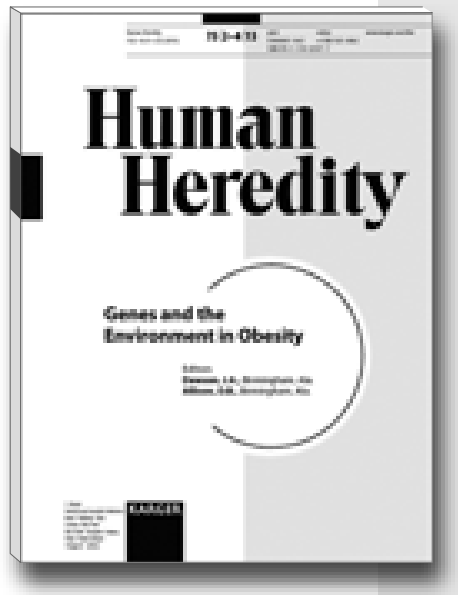

Genes and the Environment in Obesity Editors: Dawson, J.A.; Allison, D.B.

(Birmingham, Ala.)

IV + 170 p.. 32 fig. 3 in color, 31 tab., 2013

CHF 52.- / EUR 43.- / USD 61.00 (soft cover)

CHF 62.- / EUR 52.- / USD 73.00 (online)

Online version for institutional purchase

Prices subject to change

EUR price for Germany, USD price for USA and

Latin America only

ISBN 978-3-318-02477-7

e-ISBN 978-3-318-02478-4

Special Topic Issue

Human Heredity

Vol. 75, No. 2-4 (2013)

Included in subscription

Listed in MEDLINE/PubMed, Current Contents/

Life Sciences, Excerpta Medica, Biological

Abstracts, Hum-Molgen

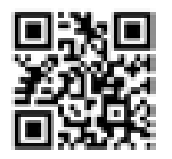

Dear Librarian

I have reviewed this publication and would like to recommend it for our library. Recommended by:

Department:

Date:

\section{Signature:}

Orders may be placed with any bookshop, subscription agency, directly with the publisher or through a Karger distributor.

\section{Genes and the Environment in Obesity}

\author{
Editors \\ John A. Dawson \\ David B. Allison
}

This publication pulls together work from more than a dozen leading obesity, energetics, and nutrition researchers working on genetic and genomic aspects of obesity. Their contributions present the latest findings from randomized controlled trials and other ongoing investigations, and direct our focus toward future genetics and epigenetic targets in our struggle with the obesity epidemic in the USA and across the globe. The topics considered range from ancestral admixture to assortative mating, from functional analysis to genome-wide association studies, and from satiety to brain anatomy. This compilation of reviews and methodological developments will help the reader to achieve a broader appreciation of the complexities of this field as well as a deeper understanding of its latest advances and important next steps.

\section{Contents}

- Functional Analysis of Seven Genes Linked to Body Mass Index and Adiposity by Genome-Wide Association Studies: A Review: Speakman, J.R. - Genetics of Food Intake Self-Regulation in Childhood: Literature Review and Research Opportunities: Faith, M.S.; Carnell, S.; Kral, T.V.E. - Epigenetics and Obesity: A Relationship Waiting to Be Explained: Symonds, M.E.; Budge, H.;

Frazier-Wood, A.C.

- Genetic Admixture and Obesity: Recent Perspectives and Future Applications: Fernández, J.R.; Pearson, K.E.; Kell, K.P.; Bohan Brown, M.M.

- Gene $\times$ Environment Interactions in Obesity: The State of the Evidence: Ahmad, S.; Varga, T.V.; Franks, P.W.

- Interface between Pharmacotherapy and Genes in Human Obesity: O'Connor, A.; Swick, A.G.

- Estimating the Range of Obesity Treatment Response Variability in Humans: Methods and Illustrations: Kaiser, K.A.; Gadbury, G.L.
- Identification of Pleiotropic Genetic Effects on Obesity and Brain Anatomy: Curran, J.E. et al. - Next-Generation Sequence Analysis of Genes Associated with Obesity and Nonalcoholic Fatty Liver Disease-Related Cirrhosis in Extreme Obesity: Gerhard, G.S. et al.

- Individual Genetic Variations Related to Satiety and Appetite Control Increase Risk of Obesity in Preschool-Age Children in the STRONG Kids Program: Wang, Y.; Wang, A.; Donovan, S.M.; Teran-Garcia, M.

- Human Cardiovascular Disease IBC Chip-Wide Association with Weight Loss and Weight Regain in the Look AHEAD Trial: McCaffery, J.M. et al.

- The Positive Association of Obesity Variants with Adulthood Adiposity Strengthens over an 80-Year Period: A Gene-by-Birth Year Interaction: Demerath, E.W. et. al.

- Impact of Informing Overweight Individuals about the Role of Genetics in Obesity: An Online Experimental Study: Lippa, N.C.; Sanderson, S.C. - Propagation of Obesity across Generations: The Roles of Differential Realized Fertility and Assortative Mating by Body Mass Index: Dawson, J.A. et al.

-TFAP2B -Dietary Protein and Glycemic Index Interactions and Weight Maintenance after Weight Loss in the DiOGenes Trial: Stocks, T. et al.

Author and Subject Index 


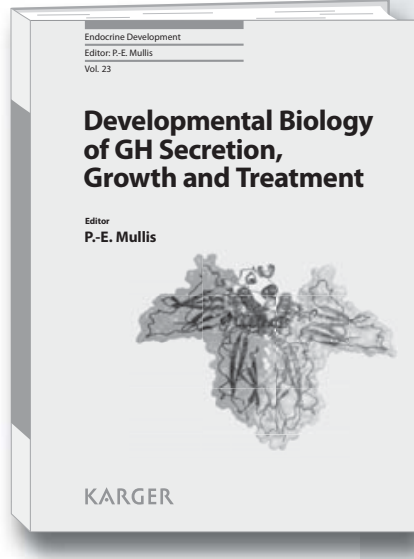

Developmental Biology of GH Secretion, Growth and Treatment

Editor: Mullis, P.-E. (Bern)

VIII + 126 p., 22 fig., 1 in color, 10 tab., 2012

CHF 156.- / EUR 130.- / USD 184.00 (hard cover)

CHF 187.- / EUR 156.- / USD 221.00 (online)

Online version for institutional purchase

Prices subject to change

EUR price for Germany, USD price for USA only

ISBN 978-3-318-02244-5 (hard cover)

e-ISBN 978-3-318-02245-2

Endocrine Development, Vol. 23

Series Editor: Mullis, P.-E. (Bern)

Listed in MEDLINE/PubMed

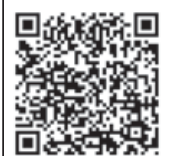

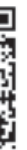

(2)

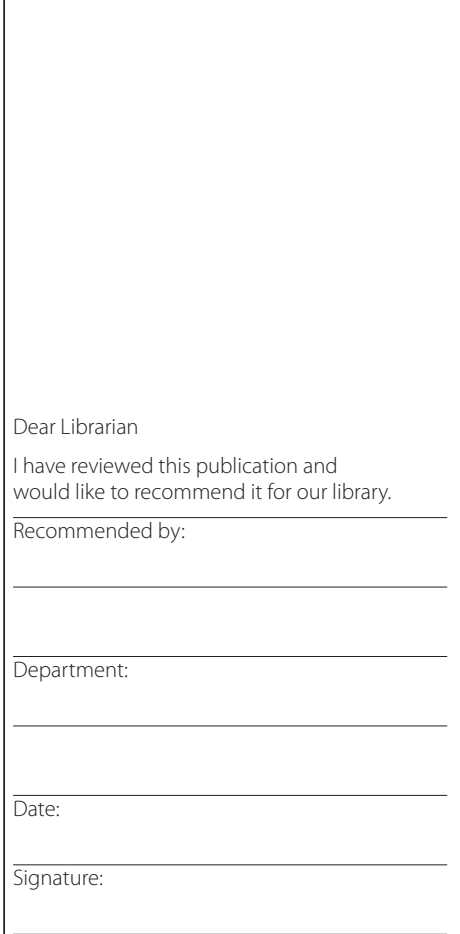

\title{
Developmental Biology of GH Secretion, Growth and Treatment
}

\author{
Editor \\ Primus-E. Mullis
}

In the last few years, rapid progress has taken place in our understanding of the developmental biology of $\mathrm{GH}$ secretion and the pivotal role it plays in growth. This book keeps the reader updated on the most important developmental aspects and influences leading to changes in terms of clinical views. In ten chapters, well-known scientists and clinicians cover some of the most important progress made in recent times. The first chapters discuss pituitary gland development and imaging in detail followed by a comprehensive presentation of the genetics of the $\mathrm{GH}$ axis. Further chapters present a detailed overview of the epigenetics and bioinformatics of $\mathrm{GH}$.

This collection of up-to-date investigative data and reviews is of relevance not only to scientists involved in endocrinology but also to any physician interested in growth and development.

\section{Contents}

-Preface: Mullis, P.-E.

- Pituitary Gland Development: An Update: Bancalari, R.E.; Gregory, L.C.; McCabe, M.J.; Dattani, M.T. . Pituitary Gland Imaging and Outcome: Di lorgi, N.; Morana, G.; Gallizia, A.L.; Maghnie, M.

-Spectrum of Insulin-Like Growth Factor Deficiency: Wit, J.M.; Oostdijk, W.; Losekoot, M.

-Downstream Insulin-Like Growth Factor: Pfäffle, R.; Kiess, W.; Klammt, J.

- New Detection Methods of Growth Hormone and Growth Factors: Bidlingmaier, M.

- Imprinted Anomalies in Fetal and Childhood

Growth Disorders: The Model of Russell-Silver and Beckwith-Wiedemann Syndromes: Netchine, I.; Rossignol, S.; Azzi, S.; Brioude, F.; Le Bouc, Y.

- Bioinformatics Tools and Databases for the Study

of Human Growth Hormone: Pandey, A.V.

-Growth Hormone and Cell Growth:Waters, M.J.; Brooks, A.J.

- From Endoplasmic Reticulum to Secretory Granules: Role of Zinc in the Secretory Pathway of Growth Hormone: Petkovic, V.; Miletta, M.C.; Mullis, P.-E.

- Isolated Growth Hormone Deficiency Type 2:

From Gene to Therapy: Miletta, M.C.; Lochmatter, D.; Pektovic, V.; Mullis, P.-E.

- Author Index / Subject Index 


\section{HORMONE \\ RESEARCH IN \\ PAEDIATRICS}

\section{Genetics of Growth}

This first special topic issue of Hormone Research in Paediatrics is completely dedicated to Genetics of Growth, a rapidly developing area of paediatric endocrinology associated with the stormy progress of genetic techniques. The topics covered in this issue include the role of zinc in the process of secretory granule biogenesis in somatotrophs; novel mutations in various parts of the growth hormone-IGF axis, including GH1, GHR, IGFALS and IGF1R; discussion of a website containing clinical, biochemical and genetic information about presently known genes in this axis; clinical characteristics of children with SHOX defects and BeckwithWiedemann syndrome, and association analysis and pharmacogenetics in relation to growth and growth response to growth hormone. The papers illustrate that in this fast moving field close collaboration between clinicians and geneticists, and between paediatric endocrinologists around the world, is necessary to solve diagnostic problems in short or tall individuals, and to get a better insight into the phenotypic spectrum of the genetic causes thereof. 